\title{
Digestibility of krill (Euphausia superba and Thysanoessa sp.) in minke whales (Balaenoptera acutorostrata) and crabeater seals (Lobodon carcinophagus)*
}

\author{
BY P.-E. MÅRTENSSON, E. S. NORDØY AND A. S. BLIX \\ Department of Arctic Biology and Institute of Medical Biology, University of Tromse, \\ $N$-9037 Tromse, Norway
}

(Received 17 January 1994 - Revised 21 March 1994 - Accepted 23 March 1994)

\begin{abstract}
Apparent digestible efficiency ( $\%$ DE) was studied by use of dietary $\mathrm{Mn}$ as an inert marker, in minke whales (Balaenoptera acutorostrata) and crabeater seals (Lobodon carcinophagus) which had been eating krill. Median \% DE in minke whales ( $n$ 5) eating krill of the genus Thysanoessa sp. (energy density (ED) $23.8 \mathrm{~kJ} / \mathrm{g}$ ) was 93 (range 87-93). Median \% DE in crabeater seals $(n \boldsymbol{6})$ eating krill of the species Euphausia superba (ED $20.8 \mathrm{~kJ} / \mathrm{g}$ ) was 84 (range 79-85), which is significantly lower than the $\% D E$ of krill in minke whales $(P=0.008)$. Since the chemical composition in $E$. superba and in Thysanoessa sp. is similar, it is suggested that the complex multi-stomached system of minke whales, which contains both chitinase (EC 3 2 2 1 14)-producing as well as several other types of bacteria, is superior to the single-stomached system of crabeater seals with regard to krill digestion. It is worth noting, however, that the \% DE of krill in the crabeater seal is still very high.
\end{abstract}

Apparent digestibility efficiency: Mn inert marker technique: Minke whale: Crabeater seal: Krill

Both minke whales (Balaenoptera acutorostrata) and crabeater seals (Lobodon carcinophagus) prey on various kinds of krill. In the north Atlantic the minke whale eats mainly Thysanoessa sp. and a variety of fish (Jonsgård, 1982; Nordøy \& Blix, 1992; Haug et al. 1993), while in the southern ocean it preys almost exclusively on Euphausia superba (Ohsumi et al. 1979). This is also the case for the Antarctic crabeater seal which preys primarily on the same species of krill (Øritsland, 1977).

The minke whales have a multi-stomached system with a large forestomach containing chitinase (EC 3.2.1.14)-producing as well as numerous other bacteria for microbial fermentation of the prey (Mathiesen et al. 1990; Olsen et al. 1994). The crabeater seal, on the other hand, relies on a single-stomached system without microbial fermentation. In the present study we have compared the abilities of minke whales and crabeater seals to digest krill using the Mn technique of Fadely et al. (1990).

\section{MATERIALS AND METHODS}

Six crabeater seals (Lobodon carcinophagus), with an age (Laws, 1958) and sex distribution given in Table 1, were killed off Queen Maud land in Antarctica $\left(70^{\circ} 25^{\prime} \mathrm{S}, 08^{\circ} 10^{\prime} \mathrm{W}\right)$ during the Nordic Antarctic Research Expedition in February 1993. The stomach and the colon of the animals were collected and frozen immediately after death and kept at $-20^{\circ}$ until analysis at the Department of Arctic Biology, University of Tromsø, Norway. All the crabeater seals had recently eaten krill ( $E$. superba), and faeces analysis confirmed that this had been the case for at least $5 \mathrm{~h}$, which is the transit time of the digesta in some other pinnipeds (Helm, 1984; Markussen, 1993).

* Publication no. 133 of the Norwegian Antarctic Research Expedition 1992/1993. 
Table 1. Sex and length of minke whales (Balaenoptera acutorostrata) and sex and age of crabeater seals (Lobodon carcinophagus)

\begin{tabular}{|c|c|c|c|c|c|}
\hline \multicolumn{3}{|c|}{ Minke whale } & \multicolumn{3}{|c|}{ Crabeater seal } \\
\hline Whale no. & Sex & Length ( $\mathrm{m}$ ) & Seal no. & Sex & Age (years) \\
\hline & & & 2 & $\mathbf{M}$ & 7.5 \\
\hline S15 & $\mathbf{F}$ & 7.97 & 3 & $\mathbf{M}$ & 19.5 \\
\hline B1 & $\mathbf{M}$ & 7.67 & 4 & $\mathbf{M}$ & 3.5 \\
\hline B14 & $\mathbf{M}$ & $7 \cdot 40$ & 5 & $\mathrm{M}$ & 2.5 \\
\hline B17 & $\mathrm{F}$ & 7.90 & 6 & $\mathrm{~F}$ & 8.5 \\
\hline B18 & $\mathbf{M}$ & 8.67 & 7 & $\mathbf{F}$ & 4.5 \\
\hline
\end{tabular}

Five minke whales (Balaenoptera acutorostrata) were killed in the north-east Atlantic during the Norwegian scientific whaling programme in July and August 1992. Forestomach and colon contents were collected and frozen immediately after death and kept at $-20^{\circ}$ until analysis. Again, forestomach and faecal analysis revealed that the animals had for some time been eating krill (Thysanoessa sp.). The transit time of the digesta of the minke whale is presently unknown.

Samples of fresh E. superba were obtained by trawling in Antarctica (February 1992) and kept frozen at $-20^{\circ}$ until analysis. The energy density (ED) of these samples was not significantly different $(P=0.39)$ from the value which was obtained on analysis of fresh stomach contents of three of the crabeater seals (Table 2). Samples of fresh Thysanoessa sp. were obtained by trawling in the Bear Island area of the Barents Sea in early August 1992, and again the samples were kept at $-20^{\circ}$ until analysis (Table 2).

Stomach contents (E. superba) and faeces from crabeater seals, as well as trawl samples of Thysanoessa sp. and faeces from minke whales, were dried at $60^{\circ}$ in an incubator to constant weight and homogenized. ED values of these samples were subsequently determined using a bomb calorimeter MK 200 (Franz Morat KG, Eisenbach, Germany). Mn concentrations in food and faeces were measured by use of a Perkin Elmer 603 atomic absorption spectrophotometer (Norwalk, CT., USA), with $279.5 \mathrm{~nm}$ wavelength, $0.2 \mathrm{~nm}$ slit width and an air-acetylene flame. Three subsamples in duplicate from each diet and one faeces sample in duplicate from each animal were analysed for energy content and $\mathrm{Mn}$ concentration (Table 2).

Subtraction of faecal energy from gross energy intake (GEI) gives the digestible energy (DE). DE can be expressed also as apparent digestible efficiency (\% DE), which is the proportion of GEI which has been absorbed through the intestinal wall and entered the bloodstream (Kleiber, 1975; Lavigne et al. 1982). To estimate \% DE a method based on dietary $\mathrm{Mn}^{2+}$ as an inert marker was used (Fadely et al. 1990); \% DE was calculated as follows: \% DE $=\left(1-\left(C_{i} \times E_{f} / C_{f} \times E_{i}\right)\right) \times 100$, where $C$ is the concentration of $M n$ and $E$ is the ED of the food $(i)$ and faeces $(f)$ expressed on a dry matter basis (modified from Kleiber, 1975).

Differences in \% DE between the diets were tested using a two-tailed Mann-Whitney $U$ test. $P<0.05$ was regarded as significant.

\section{RESULTS}

The ED and Mn concentrations of both minke whale and crabeater seal prey and faeces are given in Table 2. Median \% DE for minke whales on a krill (Thysanoessa sp.) diet was 
Table 2. Average energy density ( $E D ; k J / g$ dry weight) and manganese concentration $(\mu g / g)$ of the faeces and the krill diet of minke whales and (Balaenoptera acutorostrata) crabeater seals (Lobodon carcinophagus) eating Thysanoessa sp. and Euphausia superba respectively*

(Values are means for two determinations for faeces and for three determinations performed in duplicate for diet)

\begin{tabular}{|c|c|c|c|c|c|}
\hline & \multicolumn{2}{|l|}{ Minke whale } & \multicolumn{3}{|c|}{ Crabeater seals } \\
\hline Whale no. & $\begin{array}{c}\text { Faecal ED } \\
(\mathrm{kJ} / \mathrm{g})\end{array}$ & $\begin{array}{c}\text { Faecal Mn } \\
(\mu \mathrm{g} / \mathrm{g})\end{array}$ & Seal no. & $\begin{array}{c}\text { Faecal ED } \\
(\mathrm{kJ} / \mathrm{g})\end{array}$ & $\begin{array}{c}\text { Faecal Mn } \\
(\mu \mathrm{g} / \mathrm{g})\end{array}$ \\
\hline & & & 2 & 11.61 & 19.7 \\
\hline S15 & 11.32 & 28.8 & 3 & $12 \cdot 22$ & 19.0 \\
\hline B1 & 17.31 & $33 \cdot 2$ & 4 & 12.06 & 20.4 \\
\hline B14 & $20 \cdot 40$ & 26.8 & 5 & $11 \cdot 18$ & 18.6 \\
\hline B17 & 11.43 & 29.0 & 6 & 14.02 & 20.2 \\
\hline B18 & 12.02 & 29.4 & 7 & $13 \cdot 21$ & 16.1 \\
\hline Diet & $23 \cdot 81$ & $4 \cdot 1$ & Diet & 20.89 & $5 \cdot 3$ \\
\hline
\end{tabular}

* For details of animals and procedures, see Table 1 and pp. 713-714.

93 (range 87-93, $n 5$ ), while median \% DE for crabeater seals on a krill (E. superba) diet was 84 (range $79-85, n 6)$. These values are significantly different $(P=0.008)$.

\section{DISCUSSION}

The present study has shown that the ability to digest krill is higher in minke whales than in crabeater seals. Krill has an exoskeleton which is mainly made of chitin, which probably to some extent prevents the action of digestive enzymes on other parts of the prey. Degradation of the chitin skeleton will eliminate this barrier and also release the chemical energy bound in the chitin itself. In $E$. superba, for example, the chitin skeleton contributes about $10 \%$ to the total energy content of the animal (Clarke, 1980). Both the ED (present study) and the gross chemical composition (Saether et al. 1987) of E. superba and Thysanoessa sp. are quite similar. Mathiesen et al. (1990) have shown that the forestomach of krill-eating minke whales is rich in chitinase-producing bacteria. Such bacteria are probably responsible for the more efficient digestion of krill by minke whales compared with crabeater seals. Olsen et al. (1994), moreover, suggested that the multi-chambered stomach of minke whales increases passage time and consequently increases the time available for both microbial and enzymic digestion of such complex structures as the exoskeleton of krill.

In a previous study (Nordøy et al. 1993) based on an in vitro three-stage digestion technique simulating the different compartments of the digestive system in minke whales, a mean \% DE of 92 of herring (Clupea harengus) was obtained. When we used the present Mn method on minke whales which had eaten 0-group herring and capelin (Mallotus villosus) we got a median \% DE of 90 (range 88-92) and 95 (range 94-96) respectively (P.-E. Mårtensson, unpublished results). In another study, Mårtensson et al. (1994), using the present Mn method, obtained a $94 \%$ DE of capelin in the harp seal (Phoca groenlandicus), which feeds both on fish and crustaceans. This suggests that the complex multi-stomached system of baleen whales holds no advantage over the single-stomached system of seals when it comes to digestion of fish. However, as mentioned previously, the minke whale is significantly better than the crabeater seal in digesting krill, in spite of the 
fact that the crabeaters feed almost exclusively on krill. Moreover, the \% DE of 84 for krill in crabeater seals is almost identical to the \% DE of 83 for krill in harp seals (Mårtensson et al. 1994), which enjoy a very varied diet (e.g. Lydersen et al. 1991). This suggests that crabeaters are no better than other phocid seals in digesting crustaceans, but it should be noted that even if they are inferior to minke whales, they are still very good at it.

The authors thank the crew of $R / V$ 'Polarbjørn' for cooperation in the field. Dr Tore Haug, Norwegian Institute of Fisheries and Aquaculture, Tromsø, is thanked for coordinating the collection of forestomach and faecal material during the Norwegian scientific whaling programme in 1992; Mr Kjell T. Nilssen and Mr Ulf Lindström, Norwegian Institute of Fisheries and Aquaculture, Tromsø, are thanked for analysis of the forestomach composition of some minke whales; and $\mathrm{Mr}$ Bjørn Bergflødt, Marine Mammals Division, Institute of Marine Research, Bergen, for age determination of crabeater seals. Mr Rolf Larsen, Institute of Mathematical and Physical Sciences, Troms $\varnothing$, is also acknowledged for help in setting up the Mn analysis. This study was supported by the Norwegian Fisheries Research Council grant no. 408.008.

\section{REFERENCES}

Clarke, A. (1980). The biochemical composition of krill, Euphausia superba Dana, from South Georgia. Journal of Experimental Marine Biology and Ecology 43, 221-236.

Fadely, B. S., Worthy, G. A. J. \& Costa, D. P. (1990). Assimilation efficiency of northern fur seals determined using dietary manganese. Journal of Wildlife Management 54, 246-251.

Haug, T., Gjøsæter, H., Lindstrøm, U. \& Nilssen, K. T. (1993). Studies of minke whale Balaenoptera acutorostrata ecology in the Northeast Atlantic: preliminary results from studies of diet and food availability during summer 1992. Paper SC/45/NA3 presented to the International Whaling Commission Scientific Committee.

Helm, R. C. (1984). Rate of digestion in three species of pinnipeds. Canadian Journal of Zoology 62, $1751-1756$.

Jonsgård, A. (1982). The food of minke whales (Balaenoptera acutorostrata) in northern North Atlantic waters. Reports of the International Whaling Commission 32, 259-262.

Kleiber, M. (1975). The Fire of Life. Malabar, Florida: Robert E. Krieger Publishing Co. Inc.

Lavigne, D. M., Barchard, W., Innes, S. \& Øritsland, N. A. (1982). Pinniped bioenergetics. In Mammals in the Seas. FAO Fisheries Series no. 5, vol. 4, pp. 191-235. Rome: FAO.

Laws, R. M. (1958). Growth rates and ages of crabeater seals, Lobodon carcinophagus (Jacquinot \& Pucheran). Proceedings of the Zoological Society of London 130, 275-288.

Lydersen, C., Angantyr, L. A., Wiig, Ø. \& Øritsland, T. (1991). Feeding habits of Northeast Atlantic harp seals (Phoca groenlandica) along the summer ice edge of the Barents Sea. Canadian Journal of Fisheries and Aquatic Sciences 48, 2180-2183.

Markussen, N. H. (1993). Transit time of digesta in captive harbour seals (Phoca vitulina). Canadian Journal of Zoology 71, 1071-1073.

Mårtensson, P.-E., Nordøy, E. S. \& Blix, A. S. (1994). Digestibility of crustaceans and capelin in harp seals (Phoca groenlandica). Marine Mammal Science 10, 325-331.

Mathiesen, S. D., Aagnes, T. \& Sørmo, W. (1990). Microbial symbiotic digestion in minke whales (Balaenoptera acutorostrata). Paper SC / 42/NHMi9 presented to the International Whaling Commission Scientific Committee.

Nordøy, E. S. \& Blix, A. S. (1992). Diet of minke whales in the Northeastern Atlantic. Reports of the International Whaling Commission 42, 393-398.

Nordøy, E. S., Sørmo, W. \& Blix, A. S. (1993). In vitro digestibility of different prey species of minke whales (Balaenoptera acutorostrata). British Journal of Nutrition 70, 485-489.

Ohsumi, S. (1979). Feeding habits of the minke whale in the Antarctic. Reports of the International Whaling Commission 29, 473-476.

Olsen, M. A., Nordøy, E. S., Blix, A. S. \& Mathiesen, S. D. (1994). Functional anatomy of the gastrointestinal system of Northeastern Atlantic minke whales (Balaenoptera acutorostrata). Journal of Zoology (In the Press).

Øritsland, T. (1977). Food consumption of seals in the Antarctic pack ice. In Adaptations within Antarctic Ecosystems, pp. 749-768 [G. A. Llano, editor]. Washington, DC: Smithsonian Institution.

Saether, S., Ellingsen, T. E. \& Mohr, V. (1987). Proteolysis post mortem in north Atiantic krill. Comparative Biochemistry and Physiology 88B, 165-176. 